\title{
Synthesis and in vitro antiproliferative activity of novel (4-chloro- and 4-acyloxy-2-butynyl)thioquinolines
}

\author{
Stanisław Boryczka • Wojciech Mól • \\ Magdalena Milczarek • Joanna Wietrzyk • \\ Ewa Bębenek
}

Received: 31 December 2009/Accepted: 29 October 2010/Published online: 17 November 2010

(C) The Author(s) 2010. This article is published with open access at Springerlink.com

\begin{abstract}
The series of new acetylenic thioquinolines containing propargyl, 4-chloro-2-butynyl, and 4-acyloxy-2butynyl groups have been prepared and tested for antiproliferative activity in vitro against human [SW707 (colorectal adenocarcinoma), CCRF/CEM (leukemia), T47D (breast cancer)] and murine [P388 (leukemia), B16 (melanoma)] cancer lines. Most of the obtained compounds exhibited antiproliferative activity, especially compounds $\mathbf{8}, \mathbf{1 2}$, and 21 showed the $\mathrm{ID}_{50}$ values ranging from 0.4 to $3.8 \mu \mathrm{g} / \mathrm{ml}$ comparable to that of cisplatin used as reference compounds.
\end{abstract}

Keywords Acetylenic thioquinolines .

(4-Chloro-2-butynyl)thioquinolines .

(4-Acyloxy-2-butynyl)thioquinolines .

Antiproliferative activity

\section{Introduction}

The carbon-carbon triple bond is one of the most important functional groups in organic chemistry and pharmacology. The structure activity relationship studies suggest that introduction of alkyne motif may significantly modify the chemical, physical, and biological properties of acetylenic

S. Boryczka $(\bowtie) \cdot$ W. Mól · E. Bębenek

Department of Organic Chemistry, Medical University

of Silesia, Sosnowiec PL-41-200, Poland

e-mail: boryczka@sum.edu.pl

M. Milczarek · J. Wietrzyk

Department of Experimental Oncology, Ludwik Hirszfeld Institute of Immunology and Experimental Therapy, Polish Academy of Sciences, PL-53-114 Wrocław, Poland compounds (Ben-Zvi and Danon, 1994). Among a large group of synthetic and natural acetylenic compounds the quinolines possessing an alkynyl moieties are of particular interest as many of them display important activities, namely antimicrobiological, anticancer, antiprotozoal, and antiretroviral (Fuita et al., 1998; Fakhfakh et al., 2003; Abele et al., 2002). Several acetylenic 2,5-disubstituted decahydroquinoline alkaloids of wide spectra biological activities have been isolated from the skins of frogs, toads and related amphibians (Spande et al., 1999; Michael, 2000). It should be noted that less information is available concerning the synthesis and biological evaluation of alkynylthioquinolines (Abele et al., 2002; Makisumi and Murabayashi, 1969; Boryczka, 1999). It is noteworthy that no data about the synthesis and cytotoxic activity of quinolines containing a selenoacetylenic substituent are available. The chemical and physical properties of selenium are very similar to those of sulfur but the biochemistry differs in at least two respects that distinguish them in biological systems (Aboul-Faddl, 2005). First, in biological systems selenium compounds are metabolized to more reduced states, whereas sulfur compounds are metabolized to more oxidized states; second, selenols are more acidic than thiols, and they are readily oxidized. In general, organoselenium compounds are more reactive than their sulfur analogs due to weaker $\mathrm{C}-\mathrm{Se}$ bond than the $\mathrm{C}-\mathrm{S}$ bond. These properties can be involved in higher activity of the $\mathrm{Se}$ compounds against cancer cells than $\mathrm{S}$ derivatives (Aboul-Faddl, 2005).

The synthetic methods for preparation of acetylenic compounds are of interest especially with regard to the synthesis of enediyne antitumor antibiotics or similar molecules (Nicolaou and Dai, 1991; Grissom et al., 1996; Joshi et al., 2007; Kumar et al., 2001). Several cyclic and acyclic models have recently been developed, some of 
them including pyridine and quinoline units (Rawat et al., 2001; Knoll et al., 1988; Bhattacharyya et al., 2006).

We have reported a simple and efficient method for the synthesis of 3,4-disubstituted thioquinolines, which possess one or two the same or different $\mathrm{O}, \mathrm{S}$, Se acetylenic groups. The new acetylenic thioquinolines exhibited antiproliferative activity in vitro against a broad panel of human and murine cancer cell lines comparable to cisplatin (Boryczka et al., 2002a, 2002b; Mól et al., 2006, 2008). The structure-activity relationships study show a significant correlation between the antiproliferative activity and the electronic properties expressed as ${ }^{13} \mathrm{C}$ NMR chemical shift, lipophilicity, and molecular electrostatic potential (Boryczka et al., 2002b, 2003; Bajda et al., 2007; Boryczka et al., 2010).

It is well known that several acetylenic compounds possessing 2-butynyl motif exhibit specific pharmacological activities, although the exact role of the 2-butynyl motif in the activity of these derivatives is not fully understood (Ben-Zvi and Danon, 1994).

As an extension of our work on the development of anticancer drugs, we synthesized derivatives 6-12 and 16-25 with the aim to obtain more information about the influence of 4-chloro-2-butynyl and 4-acyloxy-2-butynyl groups on antiproliferative activity in this class of compounds.

\section{Results and discussion}

\section{Chemistry}

The synthesis of acetylenic thioquinolines 7-12 (Scheme 2) was accomplished starting with 4-chloro-3-methylthioquinoline 3 or 4-chloro-3-propargyl-thioquinoline $\mathbf{4}$ or 4 -chloro3-(4-hydroxy-2-butynylthio)quinoline $\mathbf{5}$.

Compounds 3-5 were prepared according to our previously reported methods (Boryczka et al., 2002b; Mól et al., 2008; Maślankiewicz and Boryczka, 1993). 4-Chloroquinoline 6 was synthesized as shown in Scheme 1. The starting 1 was prepared according to our published procedure (Maślankiewicz and Boryczka, 1993). Treatment of 1 with sodium methoxide in DMSO at $25^{\circ} \mathrm{C}$ gave sodium 4-chloro-3-quinolinethiolate 1-A and 4-methoxy-3-methylthioquinoline 2 , which was removed by extraction. Sodium salt 1-A after $\mathrm{S}$ alkylation using 1-bromo-4-chloro-2butyne gave $\mathbf{6}$ in $65 \%$ yield.

Compounds 3-5 were converted into 7-12 in $43-86 \%$ yields by nucleophilic displacement of chlorine atom by thiourea or selenourea in ethanol, hydrolysis of uronium salt 3-A and subsequent $\mathrm{S}$ or Se alkylation of sodium salt 3-B with 1-bromo-4-chloro-2-butyne (Scheme 2).

In order to determine whether a acyloxy substituent at C-4 of 2-butynyl group has any significant influence on the antiproliferative activity, new compounds bearing 4-acyloxy-2-butynyl groups were prepared.

The synthesis of acetylenic thioquinolines 16-25 (Scheme 3) was accomplished starting with 4-chloro-3-(4-hydroxy-2butynylthio)quinoline 5 or 4-(4-hydroxy-2-butynylthio)-3propargylthioquinoline 13 or 4-(4-hydroxy-2-butynylseleno)3-methylthioquinoline 14 or 4-(4-hydroxy-2-butynylthio)-3methylthioquinoline $\mathbf{1 5}$ which were prepared according to our previously reported methods (Mól et al., 2008).

The compounds $\mathbf{5}$ and 13-15 were converted into esters 16-25 with 42-91\% yields by reactions with acylating agents such as: $o$-phthalic anhydride, cinnamoyl chloride, and benzoyl chloride or ethyl chloroformate in dry benzene in the presence of pyridine.

The crude products were isolated from aqueous sodium hydroxide by filtration or extraction and separated by column chromatography.

\section{Antiproliferative activity}

The seventeen compounds were tested in SRB or MTT (in the case of leukemia cells) assay for their antiproliferative activity in vitro against three human cancer cell lines: SW707 (colorectal adenocarcinoma), CCRF/CEM (leukemia), T47D (breast cancer) and two murine cancer cell lines: P388 (leukemia), B16 (melanoma). The results of cytotoxic activity in vitro were expressed as an $\operatorname{ID}_{50}(\mu \mathrm{g} / \mathrm{ml})$, i.e., the concentration of compound, which inhibits the proliferation of $50 \%$ of tumor cells as compared to the control untreated cells. Cisplatin was applied as a referential cytotoxic agent (positive test control). A value of less than $4 \mu \mathrm{g} / \mathrm{ml}$ was considered as an antiproliferative activity criterion for synthetic compounds. The results of the cytotoxicity studies are summarized in Table 1, previously reported data for compounds 4-chloro-3-(4-hydroxy-2-butynylthio)-quinoline 5, 4-(4-hydroxy-2-butynylseleno)-3-methyl-thioquinoline $\mathbf{1 4}$ and 4-(4-hydroxy-2-butynylthio)-3-methylthioquinoline $\mathbf{1 5}$ were included for comparison (Mól et al., 2008).

In general all the compounds 6-12 containing 4-chloro2-butynyl substituent exhibited a potent antiproliferative activity against human and murine cancer lines applied. 4-Chloro-3-(4-chloro-2-butynylthio)quinoline 6 exhibited high activity against SW707, CCRF/CEM, T47D, B16 and moderate activity against P388. As reported previously 4-chloro-3-(4-hydroxy-2-butynylthio)quinoline 5 possessed lower cytotoxic activity than $\mathbf{6}$ except activity against the cells of P388 leukemia (Mól et al., 2008).

In the series of derivatives 7-12, the replacement of methyl group by propargyl or 4-hydroxy-2-butynyl, compounds 9,10 and 11, 12, respectively, resulted in decrease of activity. Among compounds 7-12, the selenium derivatives were more active than sulfur analogs and the 
Scheme 1 Synthesis of 4-chloro-3-(4-chloro-2butynylthio)quinoline 6 . Reagents and conditions: $a \mathrm{MeONa}, \mathrm{DMSO}, 25^{\circ} \mathrm{C}$, $30 \mathrm{~min}$; $b$ 1-bromo-4-chloro-2butyne, $\mathrm{NaOHaq}, 25^{\circ} \mathrm{C}, 30 \mathrm{~min}$<smiles>CSc1cnc2ccccc2c1Sc1cnc2ccccc2c1Cl</smiles>

1<smiles>COc1c(S(C)(=O)=O)cnc2ccccc12</smiles>

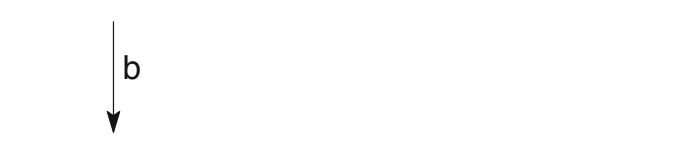<smiles>ClCC#CCc1cnc2ccccc2c1Cl</smiles>

6<smiles>[Y15]C(N)c1c(S)cnc2ccccc12</smiles>

3. $\mathrm{R}=\mathrm{CH}_{3}$

4. $\mathrm{R}=\mathrm{CH}_{2} \mathrm{C} \equiv \mathrm{CH}$

5. $\mathrm{R}=\mathrm{CH}_{2} \mathrm{C} \equiv \mathrm{CCH}_{2} \mathrm{OH}$<smiles>[R]c1c(S)cnc2ccccc12</smiles><smiles>[R5]c1cnc2ccccc2c1[N+]</smiles>

7-12

3-B

7. $\mathrm{R}=\mathrm{CH}_{3}$,

8. $\mathrm{R}=\mathrm{CH}_{3}$,

9. $\mathrm{R}=\mathrm{CH}_{2} \mathrm{C} \equiv \mathrm{CH}$,

10. $\mathrm{R}=\mathrm{CH}_{2} \mathrm{C} \equiv \mathrm{CH}$,

$\mathrm{R}^{\prime}=\mathrm{CH}_{2} \mathrm{C} \equiv \mathrm{CCH}_{2} \mathrm{Cl}, \quad \mathrm{X}=\mathrm{S}$

$\mathrm{R}^{\prime}=\mathrm{CH}_{2} \mathrm{C} \equiv \mathrm{CCH}_{2} \mathrm{Cl}, \quad X=\mathrm{Se}$

$\mathrm{R}^{\prime}=\mathrm{CH}_{2} \mathrm{C} \equiv \mathrm{CCH}_{2} \mathrm{Cl}, \quad \mathrm{X}=\mathrm{S}$

$\mathrm{R}^{\prime}=\mathrm{CH}_{2} \mathrm{C} \equiv \mathrm{CCH}_{2} \mathrm{Cl}, \quad \mathrm{X}=\mathrm{Se}$

11. $\mathrm{R}=\mathrm{CH}_{2} \mathrm{C} \equiv \mathrm{CCH}_{2} \mathrm{OH}, \mathrm{R}^{\prime}=\mathrm{CH}_{2} \mathrm{C} \equiv \mathrm{CCH}_{2} \mathrm{Cl}, \mathrm{X}=\mathrm{S}$

12. $\mathrm{R}=\mathrm{CH}_{2} \mathrm{C} \equiv \mathrm{CCH}_{2} \mathrm{OH}, \mathrm{R}^{\prime}=\mathrm{CH}_{2} \mathrm{C} \equiv \mathrm{CCH}_{2} \mathrm{Cl}, \mathrm{X}=\mathrm{Se}$

Scheme 2 Synthesis of acetylenic thioquinolines 7-12. Reagents and conditions: $a \mathrm{CS}\left(\mathrm{NH}_{2}\right)_{2}$ or $\mathrm{CSe}\left(\mathrm{NH}_{2}\right)_{2}, \mathrm{EtOH}, 25^{\circ} \mathrm{C}, 1 \mathrm{~h} ; b \mathrm{NaOHaq}$, c 1-bromo-4-chloro-2-butyne, $\mathrm{NaOHaq}, 25^{\circ} \mathrm{C}, 30 \mathrm{~min}$

selenium compound $\mathbf{8}$ showed the most potent activity with the $\mathrm{ID}_{50}$ values in the range $0.4-3.5 \mu \mathrm{g} / \mathrm{ml}$ against all cancer lines applied.

Another noteworthy feature of the obtained compounds results was the observation that leukemia (CCRF/CEM and P388) and breast cancer (T47D) cells appear to be more sensitive to the cytotoxic effects of the compounds 7-12 than two other cancer cells lines applied with $\mathrm{ID}_{50}$ value of less than $4 \mu \mathrm{g} / \mathrm{ml}$, which is considered as an antiproliferative activity criterion. It is important to note that the compounds 7-12 exhibited higher cytotoxic activity against breast cancer (T47D) cells than cisplatin.

The replacement of hydroxy group in $\mathbf{5}$ by hydrophthaloyloxy or cinnamoyloxy groups, compounds $\mathbf{1 6}$ and $\mathbf{1 7}$, resulted in decrease of activity.

The substitution of hydroxy group in 4-(4-hydroxy-2butynylseleno)-3-methylthioquinoline 14 by hydrophthaloyloxy, benzoyloxy, and cinnamoyloxy, compounds $\mathbf{1 9}$, 21, and 24, respectively, resulted in decrease of activity except activity against the cells of B16 melanoma. A structure-activity relationships observed in compounds $\mathbf{1 9}$, 21, and 24 indicated that the rank order of cytotoxic activity, against all cancer lines applied, according to the nature of the acyloxy substituent is as follows: benzoyloxy $>$ hydrophthaloyloxy $>$ cinnamoyloxy.

The replacement of hydroxy group in 4-(4-hydroxy-2butynylthio)-3-methylthioquinoline $\mathbf{1 5}$ by hydrophthaloyloxy, cinnamoyloxy, benzoyloxy, or ethoxycarbonyloxy, compounds $\mathbf{1 8}, \mathbf{2 0}, \mathbf{2 2}$, and 23 , also resulted in the decrease of activity. Comparing of compounds 18, 20, 22, and 23 indicated that the cytotoxic activity against SW707, CCRF/ CEM, T47D, and P388 were in the order ethoxycarbonyloxy $>$ hydrophthaloyloxy $>$ cinnamoyloxy $>$ benzoyloxy. Whereas the activity of these compounds against B16 was as follows: ethoxycarbonyloxy $>$ cinnamoyloxy $>$ benzoyloxy $>$ hydrophthaloyloxy. It is interesting to note that the acyloxy compounds 16-25, prepared in this study, exhibited the most potent cytotoxicity against cancer cell B16 melanoma. These results may suggest that 4-acyloxy2-butynyl function is important for anti-melanoma activity. 
Scheme 3 Synthesis of acetylenic thioquinolines 16-25. Reagents and conditions: a o-phthalic anhydride or cinnamoyl chloride, pyridine, benzene, $70^{\circ} \mathrm{C}, 1 \mathrm{~h} ; b o$-phthalic anhydride or cinnamoyl chloride or benzoyl chloride or ethyl chloroformate, pyridine, benzene, $70^{\circ} \mathrm{C}, 1 \mathrm{~h}$<smiles>OCC=CCc1cnc2ccccc2c1Cl</smiles>

16. $\mathrm{R}^{\prime}=\mathrm{COC}_{6} \mathrm{H}_{4} \mathrm{COOH}$

17. $\mathrm{R}^{\prime}=\mathrm{COCH}=\mathrm{CHC}_{6} \mathrm{H}_{5}$<smiles>[B]c1cnc2ccccc2c1C/C=C\CO</smiles>

13-15<smiles>[R9]c1cnc2ccccc2c1[Y4]</smiles>

18-25
13. $\mathrm{R}=\mathrm{CH}_{2} \mathrm{C} \equiv \mathrm{CH}, \mathrm{X}=\mathrm{S}$
14. $\mathrm{R}=\mathrm{CH}_{3}$,
$\mathrm{X}=\mathrm{Se}$
15. $\mathrm{R}=\mathrm{CH}_{3}$,
$\mathrm{X}=\mathrm{S}$
18. $\mathrm{R}=\mathrm{CH}_{3}$,
19. $\mathrm{R}=\mathrm{CH}_{3}$,
20. $\mathrm{R}=\mathrm{CH}_{3}$,
$\mathrm{R}^{\prime}=\mathrm{COC}_{6} \mathrm{H}_{4} \mathrm{COOH}, \quad X=\mathrm{S}$
21. $\mathrm{R}=\mathrm{CH}_{3}$,
$\mathrm{R}^{\prime}=\mathrm{COC}_{6} \mathrm{H}_{4} \mathrm{COOH}, \quad X=\mathrm{Se}$
$\mathrm{R}^{\prime}=\mathrm{COC}_{6} \mathrm{H}_{5}$
$\mathrm{X}=\mathrm{S}$
$\mathrm{R}^{\prime}=\mathrm{COC}_{6} \mathrm{H}_{5}$,
$\mathrm{X}=\mathrm{Se}$
22. $\mathrm{R}=\mathrm{CH}_{3}$,
$\mathrm{R}=\mathrm{COOC}_{2} \mathrm{H}_{5}$,
$\mathrm{X}=\mathrm{S}$
23. $\mathrm{R}=\mathrm{CH}_{3}$,
$\mathrm{R}^{\prime}=\mathrm{COCH}=\mathrm{CHC}_{6} \mathrm{H}_{5}, \mathrm{X}=\mathrm{S}$
24. $\mathrm{R}=\mathrm{CH}_{3}$,
$\mathrm{R}^{\prime}=\mathrm{COCH}=\mathrm{CHC}_{6} \mathrm{H}_{5}, \mathrm{X}=\mathrm{Se}$
25. $\mathrm{R}=\mathrm{CH}_{2} \mathrm{C} \equiv \mathrm{CH}, \mathrm{R}^{\prime}=\mathrm{COCH}=\mathrm{CHC}_{6} \mathrm{H}_{5}, \mathrm{X}=\mathrm{S}$

Another noteworthy feature of the obtained results was the observation that acyloxy compounds 19, 21, and 24 exhibited the most potent cytotoxicity with $\mathrm{ID}_{50}$ values $<3.1 \mu \mathrm{g} / \mathrm{ml}$ against B16 cancer cell line, among all the compounds (5-25) prepared in this study. The replacement of methyl group by propargyl, compounds 23 and $\mathbf{2 5}$, respectively, resulted in decrease of activity.

\section{Conclusions}

Novel acetylenic thioquinolines $\mathbf{6}-\mathbf{1 2}$ and $\mathbf{1 6}-\mathbf{2 5}$, possessing in positions 3 and 4, one or two, propargyl, 4-chloro-2butynyl, or 4-acyloxy-2-butynyl groups were synthesized in good yields using 4-chloro-quinoline derivatives 3-5 and 4-hydroxy-2-butynyl derivatives 13-15 as starting material. The obtained compounds were evaluated for antiproliferative activity in vitro against three human cancer cell lines: SW707 (colorectal cancer), CCRF/CEM (leukemia), T47D (breast cancer) and two murine cancer cell lines: P388 (leukemia), B16 (melanoma). All the tested compounds showed varied activity against different cancer cell lines. As a result of the SAR, it was revealed that the nature of the acetylenic substituent at the C-3 and C-4 positions and character of the heteroatoms (Se and S) at C-4 critically influence the anticancer activity in vitro of the studied compounds. Among the prepared compounds, 8, 12, and 21 were found to be the most active, with $\mathrm{ID}_{50}$ values ranging from 0.4 to $3.8 \mu \mathrm{g} / \mathrm{ml}$ comparable to that of referential anticancer drug, cisplatin. It is of interest to note that the 4-acyloxy-2-butynyl function is important for anti-melanoma activity. The obtained compounds seem to be good candidate for further anticancer activity studies in vitro using a broad panel of human and murine cell lines with the aim to select compounds for studies in vivo.

\section{Experimental}

General techniques

Melting points were determined in open capillary tubes on a Boetius melting point apparatus and are uncorrected. ${ }^{1} \mathrm{H}$ NMR (300 MHz) spectra were recorded on a Bruker MSL 300 spectrometer in $\mathrm{CDCl}_{3}$ solvents with tetramethylsilane as internal standard; chemical shifts are reported in ppm $(\delta)$ and $J$ values in $\mathrm{Hz}$. Multiplicity is designated as singlet (s), doublet (d), triplet (t), quartet (q), and multiplet (m). Mass spectra were recorded under $+\mathrm{CI}$ conditions on Finnigan MAT 95 using isobutane as a reagent and temperature of ion source of $200^{\circ} \mathrm{C}$. Elemental C, H, and $\mathrm{N}$ analyses were obtained on a Carlo Erba Model 1108 analyzer. TLC was 
Table 1 Structures of acetylenic thioquinolines 5-12, 14-25 and their antiproliferative activity in vitro and referential cisplatin against the cells of human and murine cancer cell lines

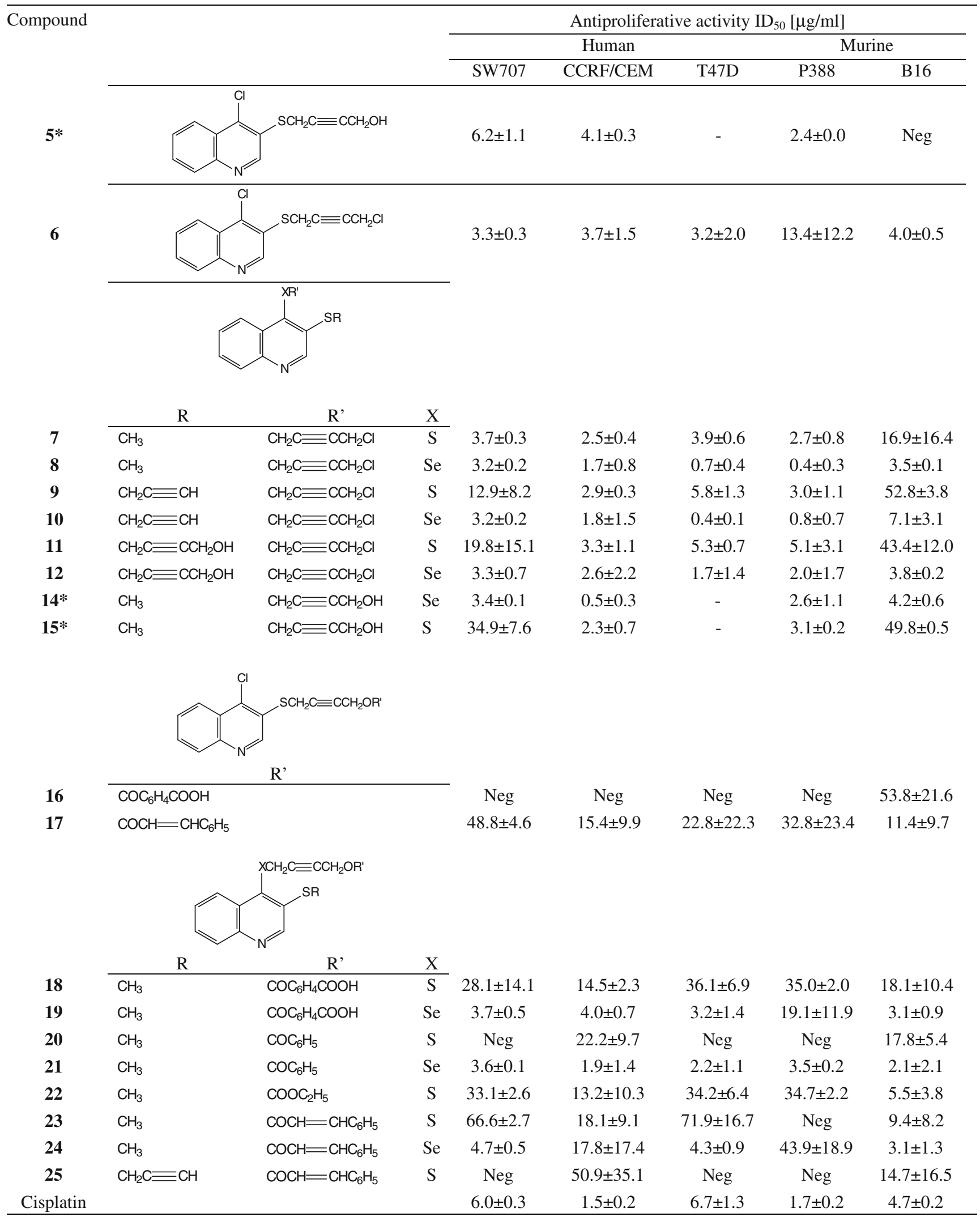

Neg Negative in the concentration used; * See ref. Mól et al., 2008 
performed on silica gel 60 254F plates (Merck) using a mixture of chloroform and ethanol $(15: 1, \mathrm{v} / \mathrm{v})$ as an eluent. UV light and iodine accomplished visualization. Column chromatography was performed on silica gel $60,<63 \mu \mathrm{m}$ (Merck) using a mixture of chloroform and ethanol (30:1, v/v) as an eluent. Solvents were dried and purified according to literature procedures.

\section{Chemistry}

The starting compounds: 4-chloro-3'-methylthio-3,4'-diquinolinyl sulfide 1 (Maślankiewicz and Boryczka, 1993), 4-chloro-3-(methylthio)quinoline 3 (Maślankiewicz and Boryczka, 1993), 4-chloro-3-propargylthioquinoline 4 (Mól et al., 2006), 4-chloro-3-(4-hydroxy-2-butynylthio)quinoline 5 (Mól et al., 2008), 1-bromo-4-chloro-2-butyne (Bailey and Fujiwara, 1955) were obtained according to methods described previously.

\section{Synthesis of 4-chloro-3-(4-chloro-2-butynylthio) quinoline 6}

A mixture of 4-chloro- $3^{\prime}$-methylthio-3,4'-diquinolinyl sulfide $1(0.74 \mathrm{~g}, 2 \mathrm{mmol})$ and sodium methoxide $(0.32 \mathrm{~g}$, $6 \mathrm{mmol}$ ) in $8 \mathrm{ml}$ DMSO was stirred at room temperature for $30 \mathrm{~min}$. The reaction mixture was poured into $20 \mathrm{ml}$ of $5 \%$ aqueous sodium hydroxide and extracted with $4 \times 5 \mathrm{ml}$ of chloroform. The combined extracts were washed with water, dried with anhydrous magnesium sulfate, and evaporated to give crude 2 . To the water layer 1-bromo-4-chloro-2-butyne $(0.33 \mathrm{~g}, 2 \mathrm{mmol})$ was added and stirred for $30 \mathrm{~min}$. The mixture was extracted with $4 \times 5 \mathrm{ml}$ of chloroform. The combined organic layer was washed with water and dried with anhydrous magnesium sulfate. After removal of the solvent the residue was purified by column chromatography using chloroform/ ethanol (30:1) to give $0.37 \mathrm{~g}(65 \%)$ pure product 6: $\mathrm{mp}$ : 139- $140{ }^{\circ} \mathrm{C},{ }^{1} \mathrm{H}$ NMR $\left(\mathrm{CDCl}_{3}\right) \delta: 3.82(\mathrm{t}, J=2.4 \mathrm{~Hz}, 2 \mathrm{H}$, $\left.\mathrm{SCH}_{2}\right), 4.06\left(\mathrm{t}, J=2.4 \mathrm{~Hz}, 2 \mathrm{H}, \mathrm{CH}_{2} \mathrm{Cl}\right), 7.67-7.80(\mathrm{~m}, 2 \mathrm{H}$, H-6 and H-7), 8.10-8.27 (m, 2H, H-5 and H-8), 8.98 (s, 1H, $\mathrm{H}-2)$. CI MS $m / z$ (rel. intensity) $286(\mathrm{M}+4,10), 284$ $(\mathrm{M}+2,65), 282(\mathrm{M}, 100)$. Anal. Calc. for $\mathrm{C}_{13} \mathrm{H}_{9} \mathrm{Cl}_{2} \mathrm{NS}: \mathrm{C}$ 55.33, H 3.21, N 4.96. Found: C 55.50, H 3.11, N 5.08.

\section{General procedure for the synthesis of acetylenic thioquinolines 7-12}

A mixture of 4-chloro-3-methylthioquinoline 3 (0.42 g, $2 \mathrm{mmol})$ or 4-chloro-3-propargylthioquinoline 4 (0.45 g, $2 \mathrm{mmol}$ ) or 4-chloro-3-(4-hydroxy-2-butynylthio)quinoline $5(0.50 \mathrm{~g}, 2 \mathrm{mmol})$ and selenourea $(0.26 \mathrm{~g}, 2.1 \mathrm{mmol})$ or thiourea $(0.16 \mathrm{~g}, 2.1 \mathrm{mmol})$ in $99.8 \%$ ethanol $(8 \mathrm{ml})$ was stirred at room temperature for $1 \mathrm{~h}$. The reaction mixture was poured into $20 \mathrm{ml}$ of $5 \%$ aqueous sodium hydroxide. 1-Bromo-4-chloro-2-butyne $(0.38 \mathrm{~g}, 2.3 \mathrm{mmol})$ was added dropwise to the aqueous layer, and the mixture was stirred for $15 \mathrm{~min}$. The resultant solid was filtered off, washed with water and air-dried to give crude products 7-12 which were separated by column chromatography using chloroform/ethanol (30:1) to give pure products 7-12.

4-(4-Chloro-2-butynylthio)-3-methylthioquinoline (7) Yield 86\%. Mp: $69-70{ }^{\circ} \mathrm{C} .{ }^{1} \mathrm{H} \mathrm{NMR}\left(\mathrm{CDCl}_{3}, 300 \mathrm{MHz}\right) \delta: 2.68$ $\left(\mathrm{s}, 3 \mathrm{H}, \mathrm{SCH}_{3}\right), 3.73\left(\mathrm{t}, J=2.1 \mathrm{~Hz}, 2 \mathrm{H}, \mathrm{CH}_{2}\right), 3.86(\mathrm{t}$, $\left.J=2.1 \mathrm{~Hz}, 2 \mathrm{H}, \mathrm{CH}_{2}\right), 7.62-7.72(\mathrm{~m}, 2 \mathrm{H}, \mathrm{H}-6$ and $\mathrm{H}-7)$, 8.11-8.59 (m, 2H, H-5 and H-8), 8.79 (s, 1H, H-2). CI MS m/ $z$ (rel. intensity) $294\left(\mathrm{M}+\mathrm{H}^{+}, 100\right), 258$ (40). Anal. Calc. for $\mathrm{C}_{14} \mathrm{H}_{12} \mathrm{ClNS}_{2}$ : C 57.23, H 4.12, N 4.77. Found: C 57.44, $\mathrm{H} 4.05, \mathrm{~N} 4.80$.

4-(4-Chloro-2-butynylseleno)-3-methylthioquinoline Yield 56\%. Mp: $67-68^{\circ} \mathrm{C} .{ }^{1} \mathrm{H} \mathrm{NMR}\left(\mathrm{CDCl}_{3}, 300 \mathrm{MHz}\right) \delta$ : $2.67\left(\mathrm{~s}, 3 \mathrm{H}, \mathrm{SCH}_{3}\right), 3.62\left(\mathrm{t}, J=2.4 \mathrm{~Hz}, 2 \mathrm{H}, \mathrm{CH}_{2}\right), 3.88(\mathrm{t}$, $\left.J=2.4 \mathrm{~Hz}, 2 \mathrm{H}, \mathrm{CH}_{2}\right), 7.61-7.70(\mathrm{~m}, 2 \mathrm{H}, \mathrm{H}-6$ and $\mathrm{H}-7)$, 8.14-8.52 (m, 2H, H-5 and H-8), 8.76 (s, 1H, H-2). CI MS $m / z$ (rel. intensity) $342\left(\mathrm{M}+\mathrm{H}^{+}, 100\right), 306$ (35). Anal. Calc. for $\mathrm{C}_{14} \mathrm{H}_{12} \mathrm{CINSSe}$ C 49.35, $\mathrm{H}$ 3.55, $\mathrm{N}$ 4.11. Found: C 49.47, H 3.38, N 4.20 .

4-(4-Chloro-2-butynylthio)-3-(propargylthio)quinoline (9) Yield 63\%. Mp: $109-110^{\circ} \mathrm{C} .{ }^{1} \mathrm{H} \mathrm{NMR}\left(\mathrm{CDCl}_{3}, 300 \mathrm{MHz}\right) \delta$ : $2.28(\mathrm{t}, J=2.7 \mathrm{~Hz}, 1 \mathrm{H}, \mathrm{CH}), 3.74\left(\mathrm{t}, J=2,4 \mathrm{~Hz}, 2 \mathrm{H}, \mathrm{CH}_{2}\right)$, $3.84\left(\mathrm{~d}, J=2.7 \mathrm{~Hz}, 2 \mathrm{H}, \mathrm{CH}_{2} \mathrm{~S}\right), 3.88(\mathrm{t}, J=2.4 \mathrm{~Hz}, 2 \mathrm{H}$, $\mathrm{CH}_{2}$ ), 7.65-7.72 (m, 2H, H-6 and H-7), 8.10-8.59 (m, 2H, H5 and H-8), 9.01 (s, $1 \mathrm{H}, \mathrm{H}-2)$. CI MS $\mathrm{m} / \mathrm{z}$ (rel. intensity) 318 $\left(\mathrm{M}+\mathrm{H}^{+}, 100\right), 282$ (20), 232 (15). Anal. Calc. for $\mathrm{C}_{16} \mathrm{H}_{12} \mathrm{ClNS}_{2}$ : C 60.46, H 3.81, N 4.41. Found: C 60.67, H $3.90, \mathrm{~N} 4.30$.

4-(4-Chloro-2-butynylseleno)-3-(propargylthio)quinoline (10) Yield 77\%. Mp: $92-93^{\circ} \mathrm{C} .{ }^{1} \mathrm{H}$ NMR $\left(\mathrm{CDCl}_{3}\right.$, $300 \mathrm{MHz}) \delta: 2.28(\mathrm{t}, J=2.7 \mathrm{~Hz}, 1 \mathrm{H}, \mathrm{CH}), 3.63(\mathrm{t}$, $\left.J=2.4 \mathrm{~Hz}, 2 \mathrm{H}, \mathrm{CH}_{2}\right), 3.82\left(\mathrm{~d}, J=2.7 \mathrm{~Hz}, 2 \mathrm{H}, \mathrm{CH}_{2} \mathrm{~S}\right)$, $3.89\left(\mathrm{t}, J=2.4 \mathrm{~Hz}, 2 \mathrm{H}, \mathrm{CH}_{2}\right), 7.66-7.72(\mathrm{~m}, 2 \mathrm{H}, \mathrm{H}-6$ and H-7), 8.07-8.53 (m, 2H, H-5 and H-8), 8.99 (s, 1H, H-2). CI MS $m / z$ (rel. intensity) $366\left(\mathrm{M}+\mathrm{H}^{+}, 100\right), 326$ (20). Anal. Calc. for $\mathrm{C}_{16} \mathrm{H}_{12} \mathrm{ClNSSe}$ : C 52.69, H 3.32, N 3.84. Found: C 52.77, H 3.40, N 3.68.

4-(4-Chloro-2-butynylthio)-3-(4-hydroxy-2-butynylthio) quinoline (11) Yield 58\%. Mp: $103-104^{\circ} \mathrm{C} .{ }^{1} \mathrm{H}$ NMR $\left(\mathrm{CDCl}_{3}, 300 \mathrm{MHz}\right) \delta: 3.75\left(\mathrm{t}, J=2.1 \mathrm{~Hz}, 2 \mathrm{H}, \mathrm{CH}_{2}\right)$, 3.87-3.89 (m, 4H, 2× $\left.\mathrm{CH}_{2}\right), 4.24(\mathrm{t}, J=2.1 \mathrm{~Hz}, 2 \mathrm{H}$, $\mathrm{CH}_{2}$ ), 7.66-7.74 (m, 2H, H-6 and H-7), 8.10-8.58 (m, 2H, $\mathrm{H}-5$ and H-8), 9.02 (s, 1H, H-2). CI MS m/z (rel. intensity) 
$348\left(\mathrm{M}+\mathrm{H}^{+}, 40\right), 362$ (55), 244 (100). Anal. Calc. for $\mathrm{C}_{17} \mathrm{H}_{14} \mathrm{ClNOS}_{2}$ : C 58.70, H 4.06, N 4.03. Found: C 58.62, $\mathrm{H} 4.15$, N 3.86 .

4-(4-Chloro-2-butynylseleno)-3-(4-hydroxy-2-butynylthio) quinoline (12) Yield 43\%. Mp: 99-100 ${ }^{\circ} \mathrm{C} .{ }^{1} \mathrm{H}$ NMR $\left(\mathrm{CDCl}_{3}, 300 \mathrm{MHz}\right) \delta: 3.64\left(\mathrm{t}, J=2.4 \mathrm{~Hz}, 2 \mathrm{H}, \mathrm{CH}_{2}\right)$, 3.86-3.89 (m, 4H, $\left.2 \times \mathrm{CH}_{2}\right), 4.24(\mathrm{t}, J=2.4 \mathrm{~Hz}, 2 \mathrm{H}$, $\mathrm{CH}_{2}$ ), 7.63-7.72 (m, 2H, H-6 and H-7), 8.06-8.49 (m, 2H, $\mathrm{H}-5$ and $\mathrm{H}-8$ ), 8.97 (s, $1 \mathrm{H}, \mathrm{H}-2$ ). CI MS $m / z$ (rel. intensity) $396\left(\mathrm{M}+\mathrm{H}^{+}, 44\right), 310$ (90), 292 (100). Anal. Calc. for $\mathrm{C}_{17} \mathrm{H}_{14}$ ClNOSSe: C 51.72, H 3.57, N 3.55. Found: C 51.90, H 3.65, N 3.42 .

General procedure for the synthesis of acetylenic thioquinolines 16-25

A mixture of 4-chloro-3-(4-hydroxy-2-butynylthio)quinoline $5(0.53 \mathrm{~g}, 2 \mathrm{mmol})$ or 4-(4-hydroxy-2-butynylthio)3-propargylthioquinoline 13 or $(0.60 \mathrm{~g}, 2 \mathrm{mmol})$ 4-(4hydroxy-2-butynylseleno)-3-methylthioquinoline 14 (0.64 g, 2 mmol) or 4-(4-hydroxy-2-butynylthio)-3-methylthioquinoline $15(0.55 \mathrm{~g}, 2 \mathrm{mmol})$ and pyridine $(0.17 \mathrm{~g}, 2.1 \mathrm{mmol})$ and $(2.1 \mathrm{mmol}) o$-phthalic anhydride or cinnamoyl chloride or benzoyl chloride or ethyl chloroformate in dry benzene $\left(8 \mathrm{ml}\right.$ ) was stirred at $70^{\circ} \mathrm{C}$ for about $1 \mathrm{~h}$ (monitored by TLC until complete consumption of starting materials) and then concentrated in vacuo. The residue was separated by column chromatography using chloroform/ethanol (30:1) to give pure products 16-25.

4-Chloro-3-(4-hydrophthaloyloxy-2-butynylthio)quinoline (16) Yield 64\%. Mp: 97-98 ${ }^{\circ} \mathrm{C} .{ }^{1} \mathrm{H}$ NMR $\left(\mathrm{CDCl}_{3}\right.$, $300 \mathrm{MHz}) \delta: 3.66\left(\mathrm{t}, J=2.1 \mathrm{~Hz}, 2 \mathrm{H}, \mathrm{CH}_{2}\right), 4.81(\mathrm{t}$, $\left.J=2.1 \mathrm{~Hz}, 2 \mathrm{H}, \mathrm{CH}_{2}\right), 7.31-7.64\left(\mathrm{~m}, 6 \mathrm{H}, \mathrm{C}_{6} \mathrm{H}_{4}\right.$ and $\mathrm{H}-6$ and $\mathrm{H}-7), 7.72-8.10$ (m, 2H, H-5 and H-8), 8.29 (s, 1H, H2). CI MS $m / z$ (rel. intensity) $412\left(\mathrm{M}+\mathrm{H}^{+}, 10\right), 246$ (100). Anal. Calc. for $\mathrm{C}_{21} \mathrm{H}_{14} \mathrm{ClNO}_{4} \mathrm{~S}$ : C 61.24, H 3.43, N 3.40. Found: C 61.42, H 3.50, N 3.31.

4-Chloro-3-(4-cinnamoyloxy-2-butynylthio)quinoline (17) Yield 60\%. Mp: $123-124^{\circ} \mathrm{C} .{ }^{1} \mathrm{H}$ NMR $\left(\mathrm{CDCl}_{3}, 300 \mathrm{MHz}\right)$ $\delta: 3.84\left(\mathrm{t}, J=2.1 \mathrm{~Hz}, 2 \mathrm{H}, \mathrm{CH}_{2}\right), 3.74(\mathrm{t}, J=2.1 \mathrm{~Hz}, 2 \mathrm{H}$, $\left.\mathrm{CH}_{2}\right), 6.37(\mathrm{~d}, J=15.9 \mathrm{~Hz}, 1 \mathrm{H}, \mathrm{CH}), 7.39-7.73(\mathrm{~m}, 8 \mathrm{H}$, $\mathrm{CH}$ and $\mathrm{C}_{6} \mathrm{H}_{5}$ and $\mathrm{H}-6$ and $\left.\mathrm{H}-7\right), 8.07-8.23$ (m, 2H, H-5 and $\mathrm{H}-8), 9.00$ (s, 1H, H-2). CI MS $\mathrm{m} / z$ (rel. intensity) 394 $\left(\mathrm{M}+\mathrm{H}^{+}\right.$, 100). Anal. Calc. for $\mathrm{C}_{22} \mathrm{H}_{16} \mathrm{ClNO}_{2} \mathrm{~S}$ : C 67.09, H 4.09, N 3.56. Found: C 67.25, H 3.91, N 3.62.

4-(4-Hydrophthaloyloxy-2-butynylthio)-3-metylthioquinoline (18) Yield 50\%. Mp: 96-97 ${ }^{\circ} \mathrm{C} .{ }^{1} \mathrm{H}$ NMR $\left(\mathrm{CDCl}_{3}\right.$, $300 \mathrm{MHz}) \delta: 2.64\left(\mathrm{~s}, 3 \mathrm{H}, \mathrm{SCH}_{3}\right), 3.61(\mathrm{t}, J=2,1 \mathrm{~Hz}, 2 \mathrm{H}$, $\left.\mathrm{CH}_{2}\right), 4.63\left(\mathrm{t}, J=2.1 \mathrm{~Hz}, 2 \mathrm{H}, \mathrm{CH}_{2}\right), 7.26-7.93(\mathrm{~m}, 6 \mathrm{H}$,
$\mathrm{C}_{6} \mathrm{H}_{4}$ and H-6 and H-7), 8.01-8.48 (m, 2H, H-5 and H-8), 8.85 (s, $1 \mathrm{H}, \mathrm{H}-2)$. CI MS $m / z$ (rel. intensity) $424\left(\mathrm{M}+\mathrm{H}^{+}\right.$, 10), 276 (100). Anal. Calc. for $\mathrm{C}_{22} \mathrm{H}_{17} \mathrm{NO}_{4} \mathrm{~S}_{2}: \mathrm{C} 62.39, \mathrm{H}$ 4.05, N 3.31. Found: C 62.55, H 4.10, N 3.22.

4-(4-Hydrophthaloyloxy-2-butynylseleno)-3-methylthioquinoline (19) Yield 52\%. Mp: $126-127^{\circ} \mathrm{C} .{ }^{1} \mathrm{H}$ NMR $\left(\mathrm{CDCl}_{3}, 300 \mathrm{MHz}\right) \delta: 2.67\left(\mathrm{~s}, 3 \mathrm{H}, \mathrm{SCH}_{3}\right), 3.51(\mathrm{t}$, $\left.J=2.4 \mathrm{~Hz}, 2 \mathrm{H}, \mathrm{CH}_{2}\right), 4.68\left(\mathrm{t}, J=2.4 \mathrm{~Hz}, 2 \mathrm{H}, \mathrm{CH}_{2}\right)$, 7.52-7.89 (m, 6H, $\mathrm{C}_{6} \mathrm{H}_{4}$ and $\mathrm{H}-6$ and $\left.\mathrm{H}-7\right), 8.09-8.40(\mathrm{~m}$, $2 \mathrm{H}, \mathrm{H}-5$ and $\mathrm{H}-8$ ), 8.78 (s, $1 \mathrm{H}, \mathrm{H}-2)$. CI MS m/z (rel. intensity) $472\left(\mathrm{M}+\mathrm{H}^{+}, 5\right), 324$ (100). Anal. Calc. for $\mathrm{C}_{22} \mathrm{H}_{17} \mathrm{NO}_{4} \mathrm{SSe}$ : C 56.17, H 3.64, N 2.98. Found: C 56.29, $\mathrm{H} 3.75$, N 3.12 .

4-(4-Benzoyloxy-2-butynylthio)-3-methylthioquinoline (20) Yield 90\%. Mp: $88-89^{\circ} \mathrm{C} .{ }^{1} \mathrm{H}$ NMR $\left(\mathrm{CDCl}_{3}, 300 \mathrm{MHz}\right) \delta$ : $2.65\left(\mathrm{~s}, 3 \mathrm{H}, \mathrm{SCH}_{3}\right), 3.74\left(\mathrm{t}, J=2.1 \mathrm{~Hz}, 2 \mathrm{H}, \mathrm{CH}_{2}\right), 4.68(\mathrm{t}$, $\left.J=2.1 \mathrm{~Hz}, 2 \mathrm{H}, \mathrm{CH}_{2}\right), 7.42-7.61\left(\mathrm{~m}, 7 \mathrm{H}, \mathrm{C}_{6} \mathrm{H}_{5}\right.$ and $\mathrm{H}-6$ and $\mathrm{H}-7), 8.15-8.59$ (m, 2H, H-5 and $\mathrm{H}-8), 8.78(\mathrm{~s}, 1 \mathrm{H}, \mathrm{H}-$ 2). CI MS $m / z$ (rel. intensity) $380\left(\mathrm{M}+\mathrm{H}^{+}, 100\right)$. Anal. Calc. for $\mathrm{C}_{21} \mathrm{H}_{17} \mathrm{NO}_{2} \mathrm{~S}_{2}$ : C 66.47, H 4.52, N 3.69. Found: C 66.34, H 4.48, N 3.78 .

4-(4-Benzoyloxy-2-butynylseleno)-3-methylthioquinoline (21) Yield 54\%. Mp: $92-93^{\circ} \mathrm{C} .{ }^{1} \mathrm{H}$ NMR $\left(\mathrm{CDCl}_{3}\right.$, $300 \mathrm{MHz}) \delta: 2.64\left(\mathrm{~s}, 3 \mathrm{H}, \mathrm{SCH}_{3}\right), 3.63(\mathrm{t}, J=2.4 \mathrm{~Hz}, 2 \mathrm{H}$, $\mathrm{CH}_{2}$ ), $4.69\left(\mathrm{t}, J=2.4 \mathrm{~Hz}, 2 \mathrm{H}, \mathrm{CH}_{2}\right), 7.42-7.99(\mathrm{~m}, 7 \mathrm{H}$, $\mathrm{C}_{6} \mathrm{H}_{5}$ and $\mathrm{H}-6$ and $\left.\mathrm{H}-7\right), 8.05-8.54$ (m, 2H, H-5 and H-8), 8.75 (s, $1 \mathrm{H}, \mathrm{H}-2)$. CI MS $m / z$ (rel. intensity) $428\left(\mathrm{M}+\mathrm{H}^{+}\right.$, 100). Anal. Calc. for $\mathrm{C}_{21} \mathrm{H}_{17} \mathrm{NO}_{2} \mathrm{SSe}$ : $\mathrm{C} 59.15, \mathrm{H} 4.02, \mathrm{~N}$ 3.28. Found: C 58.94, H 4.15, N 3.34.

4-(4-Ethoxycarbonyloxy-2-butynylthio)-3-methylthioquinoline (22) Yield 93\%. Mp: 48-49 ${ }^{\circ} \mathrm{C} .{ }^{1} \mathrm{H}$ NMR $\left(\mathrm{CDCl}_{3}\right.$, $300 \mathrm{MHz}) \delta: 1.30\left(\mathrm{t}, J=7.2 \mathrm{~Hz}, 3 \mathrm{H}, \mathrm{CH}_{3}\right), 2.68(\mathrm{~s}, 3 \mathrm{H}$, $\left.\mathrm{SCH}_{3}\right), 3.70\left(\mathrm{t}, J=2.4 \mathrm{~Hz}, 2 \mathrm{H}, \mathrm{CH}_{2}\right), 4.18(\mathrm{q}, J=7.2 \mathrm{~Hz}$, $\left.2 \mathrm{H}, \mathrm{OCH}_{2}\right), 4.85\left(\mathrm{t}, J=2.4 \mathrm{~Hz}, 2 \mathrm{H}, \mathrm{CH}_{2}\right), 7.61-7.73(\mathrm{~m}$, 2H, H-6 and H-7), 8.05-8.59 (m, 2H, H-5 and H-8), 8,79 (s, $1 \mathrm{H}, \mathrm{H}-2)$. CI MS $\mathrm{m} / \mathrm{z}$ (rel. intensity) $348\left(\mathrm{M}+\mathrm{H}^{+}, 100\right)$. Anal. Calc. for $\mathrm{C}_{17} \mathrm{H}_{17} \mathrm{NO}_{3} \mathrm{~S}_{2}$ : C 58.77, $\mathrm{H} 4.93, \mathrm{~N} 4.03$. Found: C 58.98, H 4.85, N 4.19.

4-(4-Cinnamoyloxy-2-butynylthio)-3-methylthioquinoline (23) Yield 91\%. Mp: 82-83 ${ }^{\circ} \mathrm{C} .{ }^{1} \mathrm{H}$ NMR $\left(\mathrm{CDCl}_{3}\right.$, $300 \mathrm{MHz}) \delta: 2.68\left(\mathrm{~s}, 3 \mathrm{H}, \mathrm{SCH}_{3}\right), 3.73(\mathrm{t}, J=2.1 \mathrm{~Hz}, 2 \mathrm{H}$, $\left.\mathrm{CH}_{2}\right), 4.57\left(\mathrm{t}, J=2.1 \mathrm{~Hz}, 2 \mathrm{H}, \mathrm{CH}_{2}\right), 6.36(\mathrm{~d}, J=16.2 \mathrm{~Hz}$, $1 \mathrm{H}, \mathrm{CH}), 7.39-7.68\left(\mathrm{~m}, 8 \mathrm{H}, \mathrm{CH}\right.$ and $\mathrm{C}_{6} \mathrm{H}_{5}$ and $\mathrm{H}-6$ and $\mathrm{H}-$ 7), 8.04-8.59 (m, 2H, H-5 and H-8), 8.80 (s, 1H, H-2). CI MS $m / z$ (rel. intensity) $406\left(\mathrm{M}+\mathrm{H}^{+}, 100\right)$. Anal. Calc. for $\mathrm{C}_{23} \mathrm{H}_{19} \mathrm{NO}_{2} \mathrm{~S}_{2}$ : C 68.12, H 4.72, N 3.45. Found: C 68.32, H 4.56, N 3.48 . 
4-(4-Cinnamoyloxy-2-butynylseleno)-3-methylthioquinoline (24) Yield $42 \%$. Mp: $98-99^{\circ} \mathrm{C} .{ }^{1} \mathrm{H}$ NMR $\left(\mathrm{CDCl}_{3}\right.$, $300 \mathrm{MHz}) \delta: 2.67\left(\mathrm{~s}, 3 \mathrm{H}, \mathrm{SCH}_{3}\right), 3.63(\mathrm{t}, J=2.1 \mathrm{~Hz}, 2 \mathrm{H}$, $\left.\mathrm{CH}_{2}\right), 4.58\left(\mathrm{t}, J=2.1 \mathrm{~Hz}, 2 \mathrm{H}, \mathrm{CH}_{2}\right), 6.37(\mathrm{~d}, J=15.9 \mathrm{~Hz}$, $1 \mathrm{H}, \mathrm{CH}), 7.39-7.69\left(\mathrm{~m}, 8 \mathrm{H}, \mathrm{CH}\right.$ and $\mathrm{C}_{6} \mathrm{H}_{5}$ and $\mathrm{H}-6$ and $\mathrm{H}-$ 7), 8.02-8.53 (m, 2H, H-5 i H-8), 8.77 (s, $1 \mathrm{H}, \mathrm{H}-2)$. CI MS $\mathrm{m} / \mathrm{z}$ (rel. intensity) $453\left(\mathrm{M}+\mathrm{H}^{+}, 90\right), 256$ (100). Anal. Calc. for $\mathrm{C}_{23} \mathrm{H}_{19} \mathrm{NO}_{2} \mathrm{SSe}$ : C 61.06, H 4.23, N 3.10. Found: C 60.81, H 4.12, N 3.18.

4-(4-Cinnamoyloxy-2-butynylthio)-3-(propargylthio)quinoline (25) Yield $80 \%$. Mp: $102-103^{\circ} \mathrm{C} .{ }^{1} \mathrm{H}$ NMR $\left(\mathrm{CDCl}_{3}\right.$, $300 \mathrm{MHz}) \delta: 2.27(\mathrm{t}, J=2,7 \mathrm{~Hz}, 1 \mathrm{H}, \mathrm{CH}), 3.75(\mathrm{t}$, $\left.J=2,4 \mathrm{~Hz}, 2 \mathrm{H}, \mathrm{CH}_{2}\right), 3.84\left(\mathrm{~d}, J=2.7 \mathrm{~Hz}, 2 \mathrm{H}, \mathrm{SCH}_{2}\right)$, $4.58\left(\mathrm{t}, J=2.4 \mathrm{~Hz}, 2 \mathrm{H}, \mathrm{CH}_{2}\right), 6.36(\mathrm{~d}, J=15.9 \mathrm{~Hz}, 1 \mathrm{H}$, $\mathrm{CH}), 7.39-7.69\left(\mathrm{~m}, 8 \mathrm{H}, \mathrm{CH}\right.$ and $\mathrm{C}_{6} \mathrm{H}_{5}$ and $\mathrm{H}-6$ and $\mathrm{H}-7$ ), 8.07-8.60 (m, 2H, H-5 and H-8), 9.01 (s, $1 \mathrm{H}, \mathrm{H}-2)$. CI MS $\mathrm{m} / \mathrm{z}$ (rel. intensity) $430\left(\mathrm{M}+\mathrm{H}^{+}, 20\right), 232$ (100). Anal. Calc. for $\mathrm{C}_{25} \mathrm{H}_{19} \mathrm{NO}_{2} \mathrm{~S}_{2}: \mathrm{C} 69.90, \mathrm{H} 4.46, \mathrm{~N}$ 3.26. Found: C $70.12, \mathrm{H} 4.52, \mathrm{~N} 3.38$.

\section{Antiproliferative assay in vitro}

\section{Cells}

The following established in vitro cancer cell lines were applied: SW707 (human colorectal adenocarcinoma), CCRF/CEM (human leukemia), T47D (human breast cancer), P388 (mouse leukemia), and B16 (mouse melanoma). All lines were obtained from the American Type Culture Collection (Rockville, Maryland, USA) and maintained at the Cell Culture Collection of the Institute of Immunology and Experimental Therapy, Wroclaw, Poland.

Twenty-four hours before addition of the tested agents, the cells were plated in 96-well plate (Sarstedt, USA) at a density of $10^{4}$ cells per well in $100 \mu \mathrm{l}$ of culture medium. The cells were cultured in the opti-MEM medium supplemented with $2 \mathrm{mM}$ glutamine (Gibco, Warsaw, Poland), streptomycin $(50 \mu \mathrm{g} / \mathrm{ml})$, penicillin $(50 \mathrm{U} / \mathrm{ml})$ (both antibiotics from Polfa, Tarchomin, Poland), and 5\% fetal calf serum (Gibco, Grand Island, USA). The cell cultures were maintained at $37^{\circ} \mathrm{C}$ in humid atmosphere saturated with $5 \%$ $\mathrm{CO}_{2}$.

\section{SRB assay}

The details of this technique were described by Skehan et al. (1990). The cytotoxicity assay was performed after 72-h exposure of the cultured cells to varying concentrations (from 0.1 to $100 \mu \mathrm{g} / \mathrm{ml}$ ) of the tested agents. The compounds were dissolved in 10\% DMSO to concentration of $1 \mathrm{mg} / \mathrm{ml}$, and subsequently diluted in culture medium to reach the required concentrations. DMSO, which was used as a solvent did not exert any inhibitory effect on cell proliferation. The cells attached to the plastic were fixed by gently layering cold 50\% TCA (trichloroacetic acid, Aldrich-Chemie, Germany) on the top of the culture medium in each well. The plates were incubated at $4^{\circ} \mathrm{C}$ for $1 \mathrm{~h}$ and then washed five times with tap water. The background optical density was measured in the wells filled with culture medium, without the cells. The cellular material fixed with TCA was stained with $0.4 \%$ sulforhodamine B (SRB, Sigma, Germany) dissolved in $1 \%$ acetic acid (POCh, Gliwice, Poland) for $30 \mathrm{~min}$. Unbound dye was removed by rinsing $(4 \times)$ with $1 \%$ acetic acid. The protein-bound dye was extracted with $10 \mathrm{mM}$ unbuffered tris base (POCh, Gliwice, Poland) for determination of optical density (at $540 \mathrm{~nm}$ ) in a computer-interfaced, 96well microtiter plate reader Multiskan RC photometer (Labsystems, Helsinki, Finland). Each compound in given concentration was tested in triplicates in each experiment, which was repeated 3-5 times.

\section{MTT assay}

This technique was applied for the cytotoxicity screening against mouse leukemia cells growing in suspension culture. An assay was performed after 72-h exposure to varying concentrations (from 0.1 to $100 \mu \mathrm{g} / \mathrm{ml}$ ) of the tested agents. The compounds were dissolved in $10 \%$ DMSO to concentration of $1 \mathrm{mg} / \mathrm{ml}$, and subsequently diluted in culture medium to reach the required concentrations. DMSO, which was used as a solvent did not exert any inhibitory effect on cell proliferation. For the last 3-4 h of incubation $20 \mu \mathrm{l}$ of MTT solution were added to each well (MTT: 3-(4,5-dimethylthiazol-2-yl)-2,5-diphenyl tetrazolium bromide; stock solution: $5 \mathrm{mg} / \mathrm{ml}$ ). The mitochondria of viable cells reduce the pale yellow MTT to a navy blue formazan: the more viable cells are present in well, the more MTT will be reduced to formazan. When incubation time was completed, $80 \mu \mathrm{l}$ of the lysing mixture was added to each well (lysing mixture: $225 \mathrm{ml}$ dimethylformamide, $67.5 \mathrm{~g}$ sodium dodecyl sulfate, and $275 \mathrm{ml}$ of distilled water). After $24 \mathrm{~h}$, when formazan crystals had been dissolved, the optical densities of the samples were read on an Multiskan RC photometer at $570 \mathrm{~nm}$ wavelength.

Each compound in given concentration was tested in triplicates in each experiment, which was repeated 3-5 times.

The results of cytotoxic activity in vitro were expressed as an $\mathrm{ID}_{50}$ - the dose of compound (in $\mu \mathrm{g} / \mathrm{ml}$ ) that inhibits proliferation rate of the tumor cells by $50 \%$ as compared to the control untreated cells. 
Acknowledgments This work is supported by Polish Ministry of Science and Higher Education, Grant No. N405 036 31/2655 and the Medical University of Silesia, Grant No. KNW-1-029/09.

Open Access This article is distributed under the terms of the Creative Commons Attribution Noncommercial License which permits any noncommercial use, distribution, and reproduction in any medium, provided the original author(s) and source are credited.

\section{References}

Abele R, Abele E, Rubina K, Dzenitis O, Arsenyan P, Shestakova I, Nesterova A, Domracheva I, Popelis J, Grinberga S, Lukevics E (2002) Synthesis and cytotoxicity of 3-(hetarylothio)-1-propynyl-(trimethyl)silane. Chem Heterocycl Comp 38:867-872

Aboul-Faddl T (2005) Selenium derivatives as cancer preventive agents. Curr Med Chem Anti Cancer Agents 5:637-652

Bailey WJ, Fujiwara E (1955) Mixed dihalides and halohydrins from butynediol. J Chem Soc 77:165-166

Bajda M, Boryczka S, Wietrzyk J, Malawska B (2007) Investigation of lipophilicity of anticancer-active thioquinoline derivatives. Biomed Chromatogr 21:123-131

Ben-Zvi Z, Danon A (1994) The chemistry of functional groups, supplement C2. In: Patai S (ed) The chemistry of triple bonded functional groups. Wiley, New York, pp 739-788

Bhattacharyya S, Pink M, Huffman JC, Zaleski JM (2006) Thioether coordinated metalloenediynes: syntheses, structures and thermal reactivity comparison. Polyhedron 5:550-558

Boryczka S (1999) Acetylenic derivatives of thioquinolines. Heterocycles 51:631-638

Boryczka S, Wietrzyk J, Opolski A (2002a) Synthesis and antiproliferative activity in vitro of new propargyl thioquinolines. Pharmazie 57:151-154

Boryczka S, Wietrzyk J, Nasulewicz A, Pełczyńska M, Opolski A (2002b) New propargyl thioquinolines-synthesis, antiproliferative activity in vitro and structure-activity relationships. Pharmazie 57:733-739

Boryczka S, Kulig K, Malawska B (2003) RP TLC determination of the lipophilicity of anticancer-active propargyl thioquinolines. J Planar Chromatogr 16:117-120

Boryczka S, Jastrzębska M, Nowak M, Kusz J, Wrzalik R, Wietrzyk J, Matyja M (2010) Synthesis, X-ray structure and antiproliferative activity of 3-benzylthio-4-propargylselenoquinoline. Med Chem Res 19:551-564. doi:10.1007/s00044-009-9212-x

Fakhfakh MA, Fournet A, Prina E, Mouscadet J-F, Franck X, Hocquemiller R, Figadere B (2003) Synthesis and biological evaluation of substituted quinolines: potential treatment of protozoal and retroviral co-infections. Bioorg Med Chem 11:5013-5023

Fuita M, Chiba K, Nakano J, Tominaga Y, Matsumoto J (1998) Synthesis and structure-antibacterial activity relationships of 7 (3-amino-1-propynyl and 3-amino-1-propenyl)quinolones. Chem Pharm Bull 46:631-638

Grissom JW, Gunawardena GU, Klingberg D, Huang D (1996) The chemistry of enediyne, enyne allenes and related compounds. Tetrahedron 52:6453-6518

Joshi MC, Bisht GS, Rawat DS (2007) Synthesis and antibacterial activity of phendioxy substituted cyclic enediynes. Bioorg Med Chem Lett 17:3226-3230

Knoll J, Budal K, Barenyl E (1988) Quinoline thioethers. GB Patent 2 204 583. Chem Abstr (1989) 110:154170g

Kumar D, David WM, Kerwin SM (2001) N-Propargyl-2-alkynylbenzothiazolium aza-enediynes: role of the 2-alkynylbenzothiazolium functionality in DNA cleavage. Bioorg Med Chem Lett 11:2971-2974

Makisumi Y, Murabayashi A (1969) The thio-Claisen rearrangements of allyl and propargyl 4-quinolyl sulfides. Tetrahedron Lett 24:1971-1974

Maślankiewicz A, Boryczka S (1993) Reactions of 4-methoxy-3quinolinyl and 1, 4-dihydro-4-oxo-3-quinolinyl sulfides aiming at the synthesis of 4-chloro-3-quinolinyl sulfides. J Heterocycl Chem 30:1623-1628

Michael JP (2000) Quinoline, quinazoline and acridone alkaloids. Nat Prod Rep 17:603-620

Mól W, Naczyński A, Boryczka S, Wietrzyk J, Opolski A (2006) Synthesis and antiproliferative activity in vitro of diacetylenic thioquinolines. Pharmazie 61:742-745

Mól W, Matyja M, Filip B, Wietrzyk J, Boryczka S (2008) Synthesis and antiproliferative activity in vitro of novel (2-butynyl)thioquinolines. Bioorg Med Chem 16:8136-8141

Nicolaou K, Dai W-M (1991) Chemistry and biology of the enediyne anticancer antibiotics. Angew Chem Int Ed Engl 30:1387-1416

Rawat DS, Benites PJ, Incarvito CD, Rheingold AL, Zaleski JM (2001) The contribution of ligand flexibility to metal center geometry modulated thermal cyclization of conjugated pyridine and quinoline metalloenediynes of copper (I) and copper (II). Inorg Chem 40:1846-1857

Skehan P, Storeng R, Scudiero D, Monks A, Mcmachon J, Vistica D, Warren JT, Bokesch H, Kenney S, Boyol MR (1990) New colorimetric cytotoxicity assay for anticancer-drug screening. J Natl Cancer Inst 82:1107-1112

Spande TF, Jain P, Garraffo HM, Pannell LK, Yeh HJC, Daly JW (1999) Occurrence and significance of decahydroquinolines from dendrobatid poison frogs and a myrmicine ant: use of $1 \mathrm{H}$ and 13C NMR in their conformational analysis. J Nat Prod 62:5-21 